\title{
Effects of mCPP on the Extracellular Concentrations of Serotonin and Dopamine in Rat Brain
}

\author{
Elias Eriksson, Ph.D., Göran Engberg, Ph.D., Ola Bing, B.M., \\ and Hans Nissbrandt, M.D., Ph.D.
}

\begin{abstract}
Intravenous administration of m-chloro-phenylpiperazine (mCPP) $(0.25$ or $2.5 \mathrm{mg} / \mathrm{kg})$ induced a marked and doserelated increase in extracellular concentrations of serotonin in hippocampus (300-1,400\% of baseline) as measured using in vivo microdialysis in awake male Wistar rats of the spontaneously hypertensive ( $\mathrm{SH}$ ) strain. Indicating that the effect of $m C P P$ was caused by a reversal of the serotonin transporter, it was antagonized by pretreatment with the serotonin re-uptake inhibitor citalopram $(10 \mathrm{mg} / \mathrm{kg})$ but was unaffected by local administration of the sodium channel blocker tetrodotoxin (TTX; $1 \mu \mathrm{m})$. $\mathrm{mCPP}$ was also shown to induce an increase in extracellular concentrations of dopamine in the nucleus accumbens and the striatum of $S H$ rats and in the nucleus accumbens of rats of the Sprague-Dawley (SD) strain; this effect of $m C P P$ was,
\end{abstract}

KEY WORDS: $m$-chloro-phenylpiperazine ( $m C P P)$;

Serotonin; Dopamine, In vivo microdialysis; Hippocampus; Striatum, Nucleus accumbens; Citalopram; Rat

$\mathrm{m}$-Chloro-phenylpiperazine (mCPP), the metabolite of the antidepressant drug trazodone, has recently gained marked attention as a putative probe of serotonergic function in clinical psychiatric research. Thus, the prolactin, $\mathrm{ACTH}$, and cortisol responses to $\mathrm{mCPP}$ frequently have been used as putative markers of postsyn-

From the Department of Pharmacology, University of Göteborg, Göteborg, Sweden.

Address correspondence to: Elias Eriksson, Institute of Physiology and Pharmacology, Department of Pharmacology, Göteborg University, P.O.B. 431, SE 40530 Göteborg, Sweden.

Received January 5, 1998; revised May 20, 1998; accepted June 23 1998. however, much weaker (125-170\% of baseline) than the effect on serotonin; moreover, it seems to be TTX-sensitive. In anesthetized $S D$ rats, $m C P P$ induced a moderate reduction of nigral dopamine cell firing rate; supporting the assumption that this effect is secondary to the observed increase in dopamine release, it was blocked by pretreatment either with the dopamine synthesis inhibitor alpha-methylpara-tyrosine or with the dopamine $D_{2}$ receptor antagonist haloperidol. In conclusion, the results suggest that $m C P P$ induces a marked, TTX-insensitive increase in serotonin release in rat brain, but only a modest and TTX-sensitive increase in the extracellular levels of dopamine.

[Neuropsychopharmacology 20:287-296, 1999] (C) 1999 American College of Neuropsychopharmacology. Published by Elsevier Science Inc.

aptic serotonin receptor function in various psychiatric disorders. Moreover, administration of $\mathrm{MCPP}$ has been shown to elicit, and/or aggravate, anxiety attacks in patients with panic disorder, obsessions in patients with obsessive compulsive disorder (OCD), elation in alcoholics and cocaine addicts, and positive symptoms in schizophrenic patients (see Murphy et al. 1991; Kahn and Wetzler 1991; Krystal et al. 1993; Buydens-Branchey et al. 1993; Krystal et al. 1994).

$\mathrm{mCPP}$ displays high affinity to 5 - $\mathrm{HT} 2 \mathrm{C}$ receptors and moderate, or low, affinity to 5-HT1A, 5-HT1B, 5-HT2A, 5-HT2B, and 5-HT3 receptors; in addition, the compound has some affinity for alpha-2-adrenoceptors. At the 5-HT2C receptor, $\mathrm{mCPP}$ seems to act as a partial agonist with relatively high intrinsic efficacy, whereas, at the other serotonin receptors, the intrinsic efficacy of mCPP is moderate or low (see Murphy et al. 1991; Kahn 
and Wetzler 1991). The behavioral and endocrine effects of mCPP observed in clinical studies are generally attributed to the direct effects of $\mathrm{mCPP}$ on various subtypes of serotonin receptors; in contrast, little attention has been paid to the report by Baumann et al. (1993) suggesting that $\mathrm{mCPP}$ may also stimulate serotonin release by means of an interaction with the serotonin transporter (see also Baumann et al. 1995).

To further elucidate the possible influence of $\mathrm{mCPP}$ on the release of serotonin, we studied the effects of a high dose of $\mathrm{mCPP}$ on extracellular, hippocampal concentrations of serotonin in awake, freely moving rats using in vivo microdialysis.

Enhanced dopaminergic neurotransmission has been suggested as a mechanism of importance both for the positive symptoms of schizophrenia and for the euphoria induced by such central stimulants as cocaine. The observations that mCPP may aggravate psychotic symptoms in schizophrenic patients and cause elation in cocaine addicts - in conjunction with the data of Benloucif and Galloway (1991) suggesting that local administration of mCPP within the striatum of anesthetized rats leads to a marked increase in dopamine releaseprompted us to investigate to what extent extracellular levels of dopamine in awake rats are influenced by systemic administration of mCPP. In addition, the effect of $\mathrm{mCPP}$ on the firing rate of dopaminergic neurons was investigated.

We recently found that spontaneously hypertensive (SH) rats are more reactive than other rat strains to stimuli causing anxiety attacks in panic disorder patients (such as sodium lactate and yohimbine) (see Wikander et al. 1995); hence, we also used SH rats for experiments on the mechanism of action of $\mathrm{mCPP}$. Therefore, most of the microdialysis experiments presented in this paper were performed on SH rats; however, for the electrophysiological studies, and for some of the microdialysis experiments, rats of the Sprague-Dawley (SD) strain were used. As stated in the Discussion section, the results obtained in these experiments, and in studies by others, suggest that $\mathrm{mCPP}$ exerts qualitatively similar effects on extracellular levels of monoamines in the two strains investigated. The possibility that $\mathrm{SH}$ rats and SD rats differ quantitatively with respect to how they respond to $\mathrm{mCPP}$ administration cannot be excluded; however, to compare the two strains in this respect was not within the scope of this study.

\section{MATERIALS AND METHODS}

\section{In Vivo Microdialysis/High-Performance Liquid Chromatography}

Male SH rats (250-300 g) were purchased from Møllegaard, Denmark; male SD rats (250-300 g) were purchased from ALAB (Sollentuna, Sweden). Before the ex- periments, the rats were kept under controlled conditions (temperature $21-22^{\circ} \mathrm{C}$, humidity $55-65 \%$, light on from 5 a.m. to 7 p.m.) with five animals in each cage.

The in vivo microdialysis was performed essentially as described by Waters et al. (1993) (dopamine) and Tao and Hjorth (1992) (serotonin). For the analysis of dopamine release in the nucleus accumbens and the striatum, an I-shaped probe was used (Santiago and Westerink, 1990), whereas, for the investigation of serotonin release in hippocampus, the probe used was U-shaped (Tao and Hjorth, 1992). The length of the exposed tip of the dialysis membrane was $3 \mathrm{~mm}$ (I-type) and $6 \mathrm{~mm}$ (U-type), respectively. The probes were implanted during anesthesia with the rats mounted into a stereotaxic instrument using the following coordinates, relative to bregma, according to Paxinos and Watson (1986): $\mathrm{A} / \mathrm{P}+1.0, \mathrm{~L} / \mathrm{M}-2.6$, and $\mathrm{V} / \mathrm{D}-6.2$ (striatum), $\mathrm{A} / \mathrm{P}+1.85, \mathrm{~L} / \mathrm{M}-1.6$, and $\mathrm{V} / \mathrm{D}-7.8$ (nucleus accumbens), and $\mathrm{A} / \mathrm{P}-4.6, \mathrm{~L} / \mathrm{M}+4.6, \mathrm{~V} / \mathrm{D}-8.6$ (hippocampus). During anesthesia, immediately before the implantation of the dialysis probe, a cannula was implanted into the vena jugularis. The rats were allowed to recover individually in spherical cages for $24-48 \mathrm{~h}$ before the experiment.

On the day of experiment, the rat was placed in an open cage, allowing it to move about freely. The sealed inlet and outlet of the probe were cut open with a scalpel, and the inlet cannula was connected to a perfusion pump. In the striatum and accumbens dialysis experiments, the probe was perfused with a Ringer solution, containing $\mathrm{NaCl} 140 \mathrm{~mm}, \mathrm{CaCl}_{2} 1.2 \mathrm{~mm}, \mathrm{KCl} 3.0 \mathrm{~mm}$, and $\mathrm{MgCl}_{2} 1.0 \mathrm{~mm}$ ( $\mathrm{pH}$ 5.6) (Moghaddam and Bunney 1989), at a rate of $2 \mu \mathrm{l} / \mathrm{min}$. In the hippocampal dialysis experiments, the probe was perfused with artificial CSF (pH 7.4) (for composition, see Tao and Hjorth, 1992) at a rate of $1.3 \mu \mathrm{l} / \mathrm{min}$. Samples of dialysate were collected for high-performance liquid chromotography (HPLC) analysis at $20 \mathrm{~min}$ intervals.

The dialysate was split and analyzed using two different chromatographic systems; a cation-exchange system for dopamine and serotonin and a reverse-phase system for the metabolites (DOPAC and 5-HIAA) according to a method developed by Lagerkvist (1991). On a 10-port injector with two sample loops, the main part of the sample was introduced to the cation-exchange system $(26 \mu \mathrm{l})$, and a smaller fraction $(11 \mu \mathrm{l})$ was introduced to the reverse-phase system. Following the chromatography, the detections were made by two separate electrochemical detectors. The cation-exchange system consisted of an HPLC-pump (LKB 2150, Pharmacia LKB Biotechnology Sverige AB, Sollentuna, Sweden), a pulse damper (Tillquist Analys AB, Kista, Sweden), a stainless steel column $(0.21 \times 15 \mathrm{~cm})$ packed with $\mathrm{Nu}$ cleosil, SA, $5 \mu \mathrm{m}$ (Macherey-Nagel, Düren, FRG), and an amperometric detector (Waters 460, Millipore Waters, Milford, MA, USA) operated at $0.55 \mathrm{~V}$ versus $\mathrm{Ag} / \mathrm{AgCl}$. 
The resulting current was monitored by an integrator (Hewlett-Packard integrator 3395A, USA). The mobile phase consisted of citric acid $0.049 \mathrm{~m}, \mathrm{NaOH} 0.114 \mathrm{~m}$, methanol $20 \%$, and $\mathrm{Na}_{2}$-EDTA $0.012 \mathrm{~mm}$. The flow rate was $0.25 \mathrm{ml} / \mathrm{min}$. The reverse-phase system consisted of an HPLC pump (Milton Roy miniPump VS, Riviera Beach, FL, USA), a stainless steel column $(0.21 \times 5 \mathrm{~cm})$ packed with Nucleosil, RP-18, $3 \mu \mathrm{m}$ (Macherey-Nagel, Düren, FRG), and an amperometric detector (Toli Elekronik, Göteborg, Sweden) operated at $0.80 \mathrm{~V}$ versus $\mathrm{Ag} / \mathrm{AgCl}$. The detections were carried out by a thin layer cell (TL-3 BAS, West Lafayette, IN, USA), a dual glassy carbon working electrode (TL-5A, BAS), and an $\mathrm{Ag} / \mathrm{AgCl}$ reference electrode. The resulting current was monitored by an integrator (Spectra-Physics Sp 4270, San Jose, CA, USA). The mobile phase consisted of 0.010 M K2HPO4, $0.040 \mathrm{~m}$ citric acid, $0.012 \mathrm{~mm} \mathrm{Na}$-EDTA and $5 \%$ methanol. The flow rate was $0.20 \mathrm{ml} / \mathrm{min}$.

After serotonin and dopamine levels in the dialysate had been stable for at least 1 hour, $\mathrm{mCPP}(2.5 \mathrm{mg} / \mathrm{kg})$ (Research Biochemicals International, Natick, MA, USA; dissolved in saline) or $\mathrm{NaCl}$ was administered intravenously in a volume of $0.5 \mathrm{ml}$. In one experiment, citalopram (10 mg/kg; H. Lundbeck A/S, Copenhagen; dissolved in saline) was administered subcutaneously $100 \mathrm{~min}$ before $\mathrm{mCPP}$. In some experiments, the sodium channel blocker tetrodotoxin (TTX) was added to the perfusion fluid $(1 \mu \mathrm{m})$.

\section{Electrophysiology}

Male Sprague-Dawley rats (250-300 g) were purchased from ALAB (Sollentuna, Sweden) and kept under the same conditions as described above. At the day of the experiment, the rats were anesthetised (chloral hydrate, $400 \mathrm{mg} / \mathrm{kg}, \mathrm{IP}$ ) and mounted in a conventional stereotaxic frame. $\mathrm{mCPP}$ and additional anesthetic were given through a lateral tail vein. Throughout the experiments, the body temperature of the animals was maintained at $37^{\circ} \mathrm{C}$ by means of a heating pad. The skull surface was exposed, and a 3-mm burr hole was drilled with its center located approximately $2 \mathrm{~mm}$ anterior to lambda and $2 \mathrm{~mm}$ lateral to the midline. The dura was carefully removed and a micropipette (tip diameter approximately 1-2 $\mu \mathrm{m}$ ) filled with $2 \mathrm{~m} \mathrm{NaCl}$ saturated with pontamine sky blue was lowered by means of a hydraulic microdrive (David Kopf Instr., Tujunga, CA, USA) into the region of substantia nigra, zona compacta. The in vitro impedance of the electrodes were 3 to $8 \mathrm{~m} \Omega$, measured in saline at $135 \mathrm{~Hz}$. Single unit potentials were passed through a high input impedance amplifier and filters. The impulses were discriminated from background noise and fed into a digital counter, which was reset every $10 \mathrm{~s}$, and finally displayed on a storage oscilloscope (TRIO, Tokyo, Japan), a computer (Macintosh II), an audiomonitor (Grass Instr., Quincy,
MA, USA), and a strip chart recorder (Gould Instr., Cleveland, Ohio, USA). The neurophysiological characteristics of the cells were identical to those previously described for dopaminergic neurons of substantia nigra, zona compacta (Grace and Bunney, 1983). The position of the electrode was marked at the end of each experiment by iontophoretic ejection of pontamine sky blue. The rats were then perfused with $10 \%$ buffered formalin solution and the brains were subjected to conventional histological procedures. Only results derived from rats with a correctly positioned recording electrode were included in the statistical analysis. Some rats were pretreated with a-methyl-para-tyrosine (a-MT, dissolved in saline, $250 \mathrm{mg} / \mathrm{kg}$, SC, 40-80 $\mathrm{min}$ ) or haloperidol (dissolved in a few drops of glacial acetic acid and diluted with $5 \%$ glucose solution, $0.1 \mathrm{mg} / \mathrm{kg}, \mathrm{IV}, 5$ $\mathrm{min}$ ) before the administration of $\mathrm{mCPP}$.

\section{Presentation of Data/Statistics}

The difference between the mean concentration of the two samples obtained after the intravenous injection $(\mathrm{NaCl} / \mathrm{mCPP} /$ citalopram) and the mean concentration of the two samples obtained immediately before the injection was calculated and used as a measure of druginduced change in extracellular transmitter concentrations (= "delta values"); in addition, when possible, the mean concentration of the two samples obtained after drug administration was expressed as a percentage of the mean of the two baseline values (= "\% of baseline"). Different treatment groups were compared with respect to delta values using nonparametric statistics ( $>2$ groups: Kruskal-Wallis test followed by Mann-Whitney U-test; 2 groups: Mann-Whitney U-test); repeated measures within a group were compared using Wilcoxon signed rank test. For clarity, in the figures group data are presented as means with standard errors.

\section{RESULTS}

\section{Microdialysis/Hippocampus (Serotonin)}

Baseline levels of serotonin in dialysate samples obtained form the hippocampus varied between 0.2 and $1 \mathrm{fmol} / \mu \mathrm{L}$. Whereas intravenous administration of $0.9 \%$ $\mathrm{NaCl}(0.5 \mathrm{ml})$ did not influence the extracellular concentrations of serotonin (percentage of baseline: $120 \pm 18$ ), infusion of $\mathrm{mCPP}(2.5 \mathrm{mg} / \mathrm{kg}$; IV; $0.5 \mathrm{ml})$ elicited a marked increase in the dialysate serotonin concentrations (percentage of baseline: $996 \pm 302)$ (Figure 1A). Administration of citalopram $(10 \mathrm{mg} / \mathrm{kg} ; \mathrm{SC})$ also caused a significant increase in the dialysate concentrations of serotonin (percentage of baseline: $413 \pm 44$ ); when $\mathrm{mCPP}$ was administered $(2.5 \mathrm{mg} / \mathrm{kg}$; IV, $0.5 \mathrm{ml})$ $100 \mathrm{~min}$ after the injection of citalopram, no further increase in dialysate serotonin levels was observed (per- 
centage of baseline: $107 \pm 7$ ) (Figure 1B). In rats given the sodium channel blocker TTX in the dialysis perfusion fluid, baseline dialysate serotonin concentration was below the detection limit; the $\mathrm{mCPP}(2.5 \mathrm{mg} / \mathrm{kg}$ IV; $0.5 \mathrm{ml}$ )-induced increase in dialysate serotonin concentrations was, however, comparable to that observed in rats not given TTX (Figure 1C). For statistical differences between groups, see legend to Figure 1 .

In a separate experiment, examining two different doses of $\mathrm{mCPP}(0.5$ and $2.5 \mathrm{mg} / \mathrm{kg}$; $0.5 \mathrm{ml})$, the effect of $\mathrm{mCPP}$ on dialysate serotonin concentrations was found
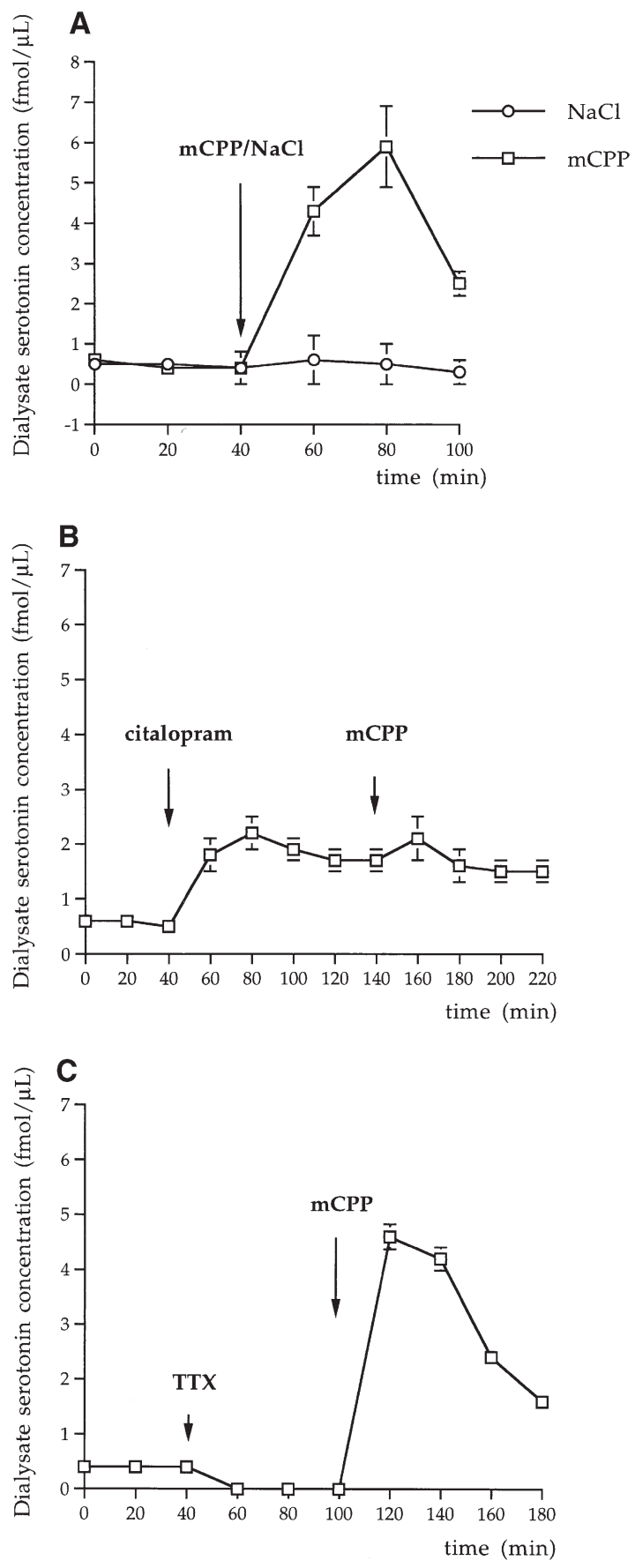

to be dose-related (Figure 2) (percentage of baseline: $315 \pm 44 \%$ and $1420 \pm 447 \%$, respectively) (for statistics, see legend to Figure 2). No consistent effects of $\mathrm{mCPP}$ on the dialysate concentrations of the serotonin metabolite 5-HIAA were observed (data not shown).

\section{Microdialysis/Nucleus Accumbens (Dopamine and Serotonin)}

Baseline levels of dopamine in dialysate samples obtained from the nucleus accumbens of $\mathrm{SH}$ rats varied between 0.6 and $4 \mathrm{fmol} / \mu \mathrm{l}$. Whereas intravenous administration of $0.9 \% \mathrm{NaCl}(0.5 \mathrm{ml})$ did not markedly influence the extracellular concentrations of dopamine (percentage of baseline: $107 \pm 4$ ), infusion of $\mathrm{mCPP}$ (2.5 $\mathrm{mg} / \mathrm{kg}$; IV; $0.5 \mathrm{ml}$ ) induced a moderate but significant increase in the dialysate dopamine concentration (percentage of baseline: $171 \pm 28 \%$ ); this effect was completely counteracted when TTX was added to the dialysis perfusion fluid (percentage of baseline: $107 \pm 11$ ) (Figure 3A). For statistical significances between groups, see legend to Figure 3.

After administration of $\mathrm{mCPP}$, concentrations of the dopamine metabolite DOPAC in dialysate obtained from the nucleus accumbens were moderately, but significantly, increased (mean \pm SEM of two samples obtained before and after $\mathrm{mCPP}$, respectively: $339 \pm 20$ and $378 \pm 24 ; n=12 ; \mathrm{z}=2.7 ; p<.01 ;$ Wilcoxon signed rank test).

A moderate, but significant, increase in extracellular dopamine levels following administration of $\mathrm{mCPP}$ was also observed in rats of the SD strain (percentage of baseline: mCPP: $138 \pm 8, \mathrm{NaCl}: 105 \pm 3$ ) (Figure 3B). Baseline levels of dopamine in dialysate samples ob-

Figure 1. mCPP induces a citalopram-sensitive but TTXinsensitive increase in extracellular concentrations of serotonin in rat hippocampus. Shown is the concentration of serotonin in dialysate samples obtained every $20 \mathrm{~min}$ from the hippocampus of awake $\mathrm{SH}$ rats administered (A) $\mathrm{NaCl}(n=6)$ or $\mathrm{mCPP}(2.5 \mathrm{mg} / \mathrm{kg}, \mathrm{IV})(n=8)$, (B) citalopram $(10 \mathrm{mg} / \mathrm{kg} \mathrm{SC})+$ $\mathrm{mCPP}(2.5 \mathrm{mg} / \mathrm{kg}, \mathrm{IV})(n=6)$, or (C) TTX (in the dialysate probe $)+\operatorname{mCPP}(2.5 \mathrm{mg} / \mathrm{kg}, \mathrm{IV})(n=4)$. Values represent means \pm SEM. The mCPP- (or $\mathrm{NaCl}$ )-induced changes in dialysate serotonin concentrations in the different groups were expressed as the difference between the mean serotonin concentration of the two samples obtained after the administration of $\mathrm{mCPP}$ (or $\mathrm{NaCl}$ ) and the mean serotonin concentration of the two samples obtained immediately before the administration of $\mathrm{mCPP}$ (or $\mathrm{NaCl}$ ), and compared by means of Kruskal-Wallis test followed by Mann-Whitney U-test. H-value: 17.4 ( $p=.0006)$. $\mathrm{NaCl}$ vs. mCPP: U-value $0.0(p=$ .002). $\mathrm{NaCl}$ vs. citalopram + mCPP: U-value 1.5 (ns). $\mathrm{NaCl}$ vs. TTX + mCPP: U-value $0.0(p=.01)$. mCPP vs. citalopram + mCPP: U-value $0.0(p=.002)$. mCPP vs. TTX + mCPP: U-value 12.0 (ns). 


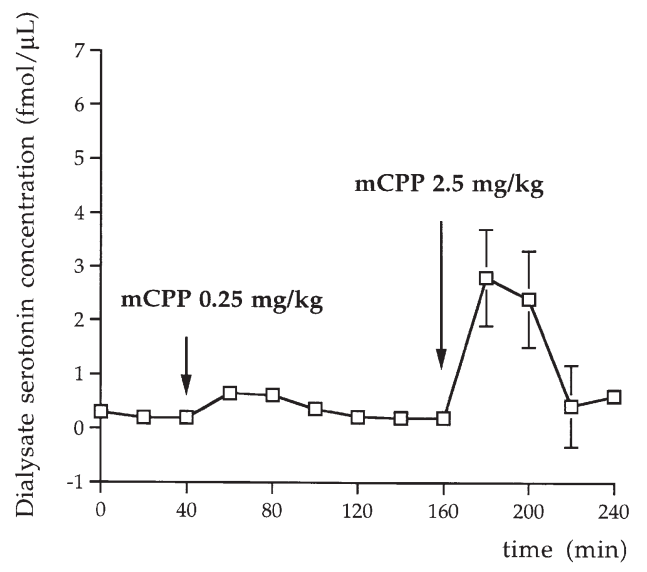

Figure 2. The effect of mCPP on extracellular concentrations of serotonin in hippocampus is dose-related. Shown is the effect of intravenous administration of two different doses of $\mathrm{mCPP}$ ( 0.25 and $2.5 \mathrm{mg} / \mathrm{kg}$, respectively) on the concentration of serotonin in dialysate samples obtained every $20 \mathrm{~min}$ from the hippocampus of awake $\mathrm{SH}$ rats $(n=$ $5)$. Values are given as means \pm SEM. The difference between the mean of the two samples obtained after the administration of the low and high dose of $\mathrm{mCPP}$, respectively, was statistically evaluated by means of the Wilcoxon Signed Rank Test $(z=2.0, p=.04)$.

tained from the nucleus accumbens of SD rats varied between 0.8 and $4.5 \mathrm{fmol} / \mu \mathrm{L}$. In the same experiment, $\mathrm{mCPP}$ was shown to induce a marked increase in serotonin levels in the nucleus accumbens of $\mathrm{SD}$ rats (mCPP: baseline levels: $0.13 \pm 0.02 \mathrm{fmol} / \mu \mathrm{L}$, post-treatment levels: $0.81 \pm 0.1 \mathrm{fmol} / \mu \mathrm{L}$, percentage of baseline: $693 \pm 81, n=10 ; \mathrm{NaCl}$ : baseline levels: $0.16 \pm 0.02$ $\mathrm{fmol} / \mu \mathrm{L}$, post-treatment levels: $0.14 \pm 0.02 \mathrm{fmol} / \mu \mathrm{L}$, percentage of baseline: $95 \pm 6, n=13$; difference between groups with respect to $\Delta$ values: $p<.0001$ ) (rats displaying nondetectable levels of serotonin before drug administration were excluded). The maximal baseline level of serotonin in a dialysate sample obtained from the nucleus accumbens of SD rats was $0.4 \mathrm{fmol} / \mu \mathrm{L}$.

\section{Microdialysis/Striatum (Dopamine)}

Baseline levels of dopamine in dialysate samples obtained from the striatum of $\mathrm{SH}$ rats varied between 4 and $10 \mathrm{fmol} / \mu \mathrm{L}$. Whereas intravenous administration of $0.9 \% \mathrm{NaCl}(0.5 \mathrm{ml})$ did not significantly increase the extracellular concentrations of dopamine, administration of mCPP $(2.5 \mathrm{mg} / \mathrm{kg})$ moderately but significantly enhanced dialysate dopamine concentrations (mCPP: baseline levels: $4.9 \pm 0.7 \mathrm{fmol} / \mu \mathrm{L}$, post-treatment levels: $5.8 \pm 0.6 \mathrm{fmol} / \mu \mathrm{L}$, percentage of baseline: 123.8 , $n=10 ; \mathrm{NaCl}$ : baseline levels: $6.4 \pm 1.4 \mathrm{fmol} / \mu \mathrm{L}$, posttreatment levels: $6.0 \pm 3.0 \mathrm{fmol} / \mu \mathrm{L}$, percentage of base-
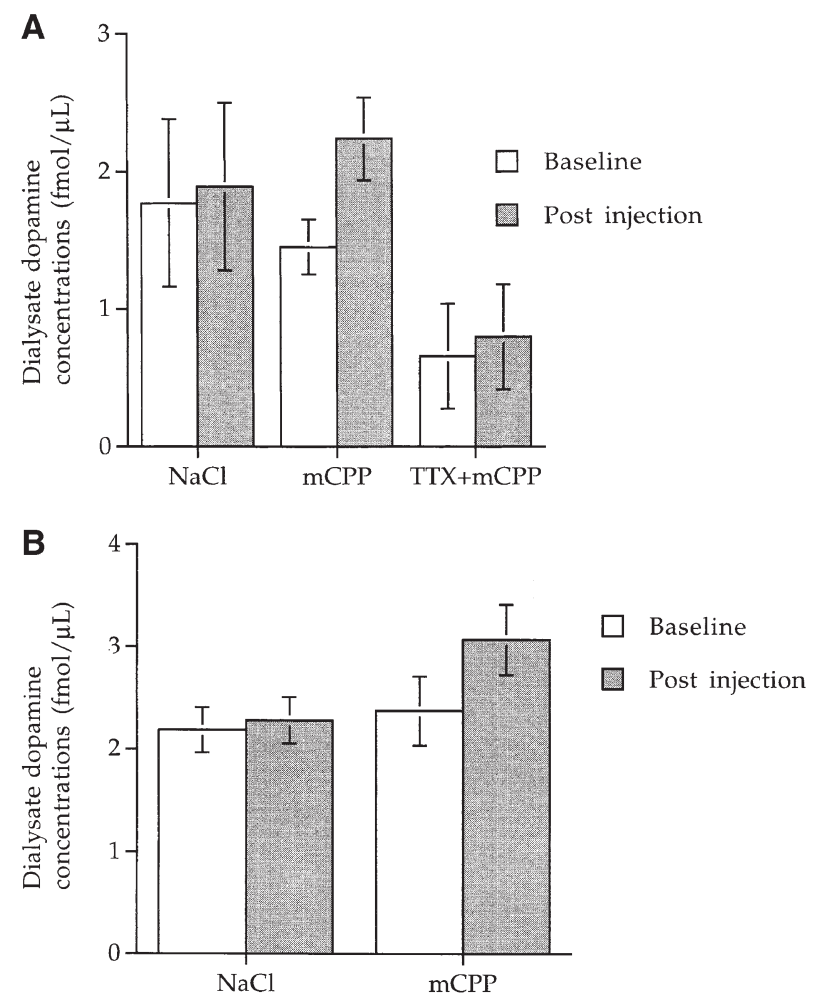

Figure 3. $\mathrm{mCPP}$ induces a weak increase in extracellular concentrations of dopamine in rat nucleus accumbens and striatum. Shown is the effect of administration of mCPP (2.5 $\mathrm{mg} / \mathrm{kg}, \mathrm{IV}, 0.5 \mathrm{ml})$ or $\mathrm{NaCl}(0.5 \mathrm{ml})$ on the concentration of dopamine in dialysate samples obtained every $20 \mathrm{~min}$ from the nucleus accumbens of SH (A) or SD (B) rats. Bars represent the mean dopamine concentration of the two samples obtained before the administration of $\mathrm{mCPP}$ (or $\mathrm{NaCl}$ ) and the mean dopamine concentration of the two samples obtained after the injection (group means \pm SEM). In the experiment shown in graph A, a third group was given TTXcontaining dialysate solution $+\mathrm{mCPP}$. In $\mathrm{SH}$ rats (graph A), the delta value ( $=$ the difference between the two samples obtained after and before injection, respectively) was significantly larger in rats receiving $\operatorname{mCPP}(n=15)$ than in those treated with $\mathrm{NaCl}(n=5)(p=.008)$ or with TTX $+\mathrm{mCPP}$ $(n=4)(p=.03)$; the groups given $\mathrm{NaCl}$ and TTX + mCPP, respectively, did not differ significantly. In SD rats (graph B), the delta value was significantly larger in rats receiving $\operatorname{mCPP}(n=12)$ than in those treated with $\mathrm{NaCl}(n=21)(p=$ .0006). Statistics: Kruskal-Wallis test followed by the MannWhitney U-test (A), or Mann-Whitney U-test only (B).

line: $95 \pm 3, n=13$; difference between groups with respect to $\Delta$ values: $p=.03$ ).

After administration of $\mathrm{mCPP}$, concentrations of the dopamine metabolite DOPAC in dialysate obtained from the striatum were moderately but significantly increased (mean \pm SEM of two samples obtained before and after mCPP, respectively: $567 \pm 69$ and $633 \pm 66$; $n=9 ; \mathrm{z}=2.5 ; p<.05 ;$ Wilcoxon signed rank test). 


\section{Electrophysiology}

Intravenous administration of $\mathrm{mCPP}$ was associated with a moderate, but dose-dependent, inhibition of all nigral dopaminergic neurons recorded from (Figure 4). Maximal effect (30\% inhibition) was obtained following a dose of $0.5 \mathrm{mg} / \mathrm{kg}$. Intravenous administration of $\mathrm{mCPP}$ in doses higher than $0.5 \mathrm{mg} / \mathrm{kg}$ was associated with a high degree of mortality, probably caused by an interaction between the drug and chloral hydrate. The mCPP-induced inhibition of dopamine cell firing rate was effectively antagonized by pretreatment either with the dopamine synthesis inhibitor a-methyl-paratyrosine (a-MT, $250 \mathrm{mg} / \mathrm{kg}, 40-80 \mathrm{~min}$ ) or with the dopamine $\mathrm{D}_{2}$ receptor antagonist haloperidol $(0.1 \mathrm{mg} /$ $\mathrm{kg}$, IV, $5 \mathrm{~min}$ ) (Figure 4).

\section{DISCUSSION}

The present study shows that systemic administration of mCPP effectively increases extracellular concentrations of serotonin in the hippocampus of $\mathrm{SH}$ rats. As expected (Sabol et al. 1992b; Rutter and Auerbach, 1993), a high dose of the serotonin reuptake inhibitor (SRI) citalopram also caused increased extracellular concentrations of serotonin in the hippocampus; however, this effect was less pronounced than that of $\mathrm{mCPP}$.

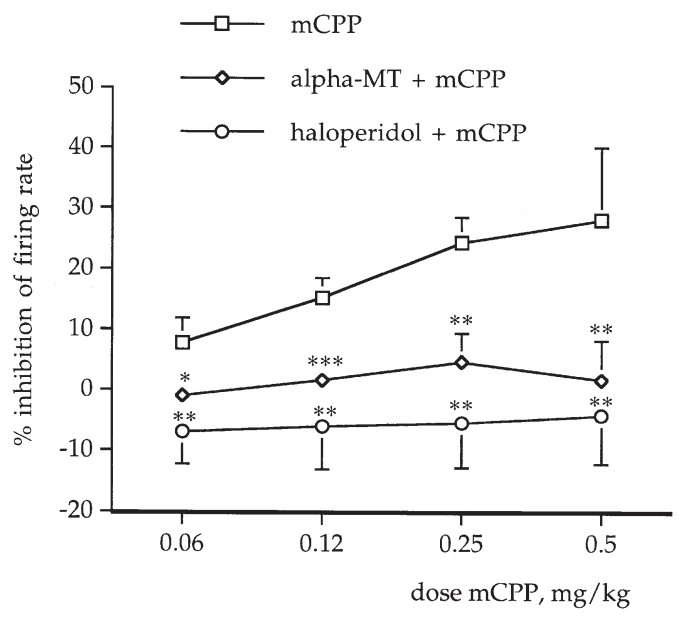

Figure 4. mCPP-induced reduction in the firing rate of nigral dopamine neurons is antagonized by dopamine synthesis inhibition. Cumulative dose response curve showing the inhibitory action of intravenously administered mCPP on the firing rate of nigral dopamine neurons in control rats and in rats pretreated with alpha-methyl-p-tyrosine (alphaMT) $(250 \mathrm{mg} / \mathrm{kg}, \mathrm{IP}, 40-80 \mathrm{~min})$ or haloperidol $(0.1 \mathrm{mg} / \mathrm{kg}$, $\mathrm{IV}, 5 \mathrm{~min})$. Each point represents the mean $\pm \mathrm{SEM} ; n=4-10$ in each group. The three groups were statistically compared using the Kruskal-Wallis test followed by the Mann-Whitney U-test $\left(^{*} p<.05 ;{ }^{* *} p<.001 ;{ }^{* *} p<.001\right)$.
The finding that the serotonin release induced by $\mathrm{mCPP}$ was counteracted by pretreatment with citalopram indicates that it is not attributable to an interaction with serotonergic autoreceptors; thus, if the effect of mCPP was attributable to autoreceptor antagonism, it should be potentiated, rather than attenuated, by pretreatment with an SRI. The previous observation that the serotonin release induced by fenfluramine is prevented by pretreatment with reuptake inhibitors (Sabol et al. 1992b) has led to the hypothesis that fenfluramine, in an amphetamine-like manner (Butcher et al. 1988), causes serotonin release by reversing the transport mechanism normally removing the transmitter from the synaptic cleft; the present data indicate that $\mathrm{mCPP}$ has a similar mode of action. The concept that mCPPinduced serotonin release is not dependent upon exocytosis lends further support from the finding that it was not modified by co-administration of the sodium channel blocker TTX; similarly, fenfluramine- and amphetamine-induced serotonin release is not affected by TTX (Carboni and Di Chiara 1989; Matos et al. 1990).

The finding that citalopram prevents $\mathrm{mCPP}$-induced serotonin release may offer an explanation to the unexpected finding of Mai and Moryl (1992) that acute pretreatment with either of the two SRIs sertraline or citalopram antagonizes mCPP-induced decrease in locomotion. Of interest in this context is also the observation that the symptom aggravation induced by $\mathrm{mCPP}$ in patients with OCD is prevented by subchronic pretreatment with SRIs (Zohar et al. 1988; Hollander et al. 1991); whether also acute pretreatment with an SRI may prevent the clinical effects of $\mathrm{mCPP}$ has, to our knowledge, not been investigated.

After we had undertaken the serotonin microdialysis experiments presented in this paper, a fluoxetinereversible stimulatory effect of $\mathrm{mCPP}$ on serotonin release in the diencephalon of SD rats was reported by Bauman and co-workers (1993). The magnitude of the effect of $\mathrm{mCPP}$ in that study was comparable to that shown in this report; thus, the effect of mCPP seems to be qualitatively the same in $\mathrm{SD}$ rats as in $\mathrm{SH}$ rats. The assumption that a marked effect of $\mathrm{mCPP}$ on extracellular levels of serotonin may be induced not only in SH rats but also in rats of the SD strain lends further support from the present finding of a marked mCPPinduced increase in extracellular concentration of serotonin in the nucleus accumbens of SD rats.

A serotonin-releasing effect of $\mathrm{mCPP}$, mediated by the serotonin transporter, also gains support from previous in vitro studies by Pettibone and Williams (1984); thus, in hypothalamic slices, $\mathrm{mCPP}$, as did fenfluramine, was shown to cause enhanced release of serotonin. Moreover, the mCPP analog 1-(m-trifluoromethylphenyl)piperazine (TFMPP) also has been shown to induce serotonin release both in vitro (Benloucif and Galloway 1991) and in vivo (Auerbach et al. 1991). In 
contrast, $\mathrm{mCPP}$ does not induce serotonin release from human platelets (Carver et al. 1993).

When interpreting the data obtained in clinical studies using $\mathrm{mCPP}$ as a pharmacological tool, the possibility that the effects of the drug, at least partly, are caused by the release of endogenous serotonin should be considered. Thus, whereas previous discussions on the mode of action of mCPP have focused on the serotonin receptor subtypes for which the compound displays affinity, the finding that $\mathrm{mCPP}$ is an indirect serotonin agonist implies that all serotonin receptors situated in the vicinity of serotonergic nerve terminals, and not concomitantly antagonized by $\mathrm{mCPP}$, may be activated by the drug. That an influence of $\mathrm{mCPP}$ on the serotonin transporter may be of importance for the functional effects of the drug was supported by the observation of Baumann and co-workers (1993) that mCPP-induced increase in prolactin release is partially counteracted by acute pretreatment with fluoxetine. Confirming that the effects of $\mathrm{mCPP}$ on the serotonin transporter may be of significance not only in rat but also in humans, $\mathrm{mCPP}$ was recently reported to display affinity for the human serotonin transporter (Baumann et al. 1995).

Given the similarity in pharmacological profile between $\mathrm{mCPP}$ and fenfluramine, it is of interest that fenfluramine, as $\mathrm{mCPP}$, has been reported to induce anxiety attacks in panic disorder patients (Targum and Marshall 1989) and to aggravate psychotic symptomatology (Marshall et al. 1989; Soper et al. 1990). Of interest in this context is also the fact that high doses of serotonin reuptake inhibitors may cause an initial aggravation of anxiety when administered to patients with panic disorder (George et al. 1995; see also Eriksson and Humble 1990). Thus, although long-term facilitation of serotonergic neurotransmission effectively reduces panic attacks and obsessive compulsive symptomatology (see Eriksson and Humble 1990), an abrupt increase in synaptic serotonin concentrations may exert the opposite effects.

Despite its marked serotonin-releasing effect, $\mathrm{mCPP}$, in contrast to fenfluramine (Trulson and Jacobs 1976), does not induce the so-called serotonergic behavioral syndrome in rats (Lucki et al. 1989; Eriksson and Nissbrandt, unpublished observation) unless given at doses tenfold higher than those used in the present study (Freo et al. 1990). Possibly, this failure of mCPP to elicit serotonin-related behavior is attributable to the fact that the drug acts as an antagonist, or a partial agonist, at several postsynaptic receptor subtypes (such as 5-HT1A and 5-HT2) (Murphy et al. 1991; Kahn and Wetzler 1991), hence protecting these receptors from the increased synaptic concentration of transmitter.

Another important difference between fenfluramine and mCPP is that the former (Ivernizzi et al. 1991; Sabol et al. 1992a) but not the latter (Fuller et al. 1981; Ulrichsen et al. 1992) drug induces both an acute and a long- lasting reduction in brain levels of serotonin. The acute reduction of brain serotonin concentration after administration of fenfluramine is probably caused by an increased activation of synthesis-regulating autoreceptors (Gardier et al. 1992); the inherent partial autoreceptor antagonism displayed by $\mathrm{mCPP}$ may, thus, explain why this compound does not cause the same effect. The mechanism for the long-lasting neurotoxic effects of fenfluramine is still a matter of controversy. Previous reports have provided indirect support for the assumption that the neurotoxic effects of fenfluramine and related serotonin-releasing compounds are not caused by the serotonin release per se (Hekmatpanah et al. 1989; Huang et al. 1992); the finding that mCPP is a forceful serotonin releaser without causing neurotoxic effects lends further support for this concept.

In the present study, using awake and freely moving $\mathrm{SH}$ rats, systemically administered $\mathrm{mCPP}$ induced a moderate, but significant, increase in the extracellular levels of dopamine in the nucleus accumbens and in the striatum; a similar effect was observed also in rats of the $\mathrm{SD}$ strain. Likewise, local perfusion of $\mathrm{mCPP}$ has previously been shown to induce an increase in dopamine release in the striatum of anesthetized rats (Benloucif and Galloway 1991). The effect of mCPP on extracellular dopamine levels was modest, as compared to the effect on serotonin; thus, whereas the dialysate serotonin concentrations after $\mathrm{mCPP}$ administration $(2.5 \mathrm{mg} / \mathrm{kg})$ were always $>600 \%$ of baseline, dopamine concentrations increased to $120-170 \%$ of baseline only. The functional significance of such a weak increase in dopamine levels may be questioned; however, given the putative involvement of dopamine in schizophrenia and reward mechanisms, the possibility that a dopamine-releasing effect of mCPP may be of importance for the behavioral effects observed after administration of the drug to patients with schizophrenia (Iqbal et al. 1991; Kahn et al. 1992; Krystal et al. 1993) and drug addiction (Benkelfat et al. 1991; Buydens-Branchey et al. 1993; Krystal et al. 1994) should not be excluded.

The finding that the effect of $\mathrm{mCPP}$ on dopamine release in the nucleus accumbens was abolished by coadministration of TTX suggests that this effect is not caused by a reversal of the dopamine transporter but to a calcium-dependent mechanism. However, the firing rate of dopaminergic neurons in the ventral tegmental area (VTA) (Prisco et al. 1994) and substantia nigra (Kelland et al. 1990; this study) of anesthetized rats is reduced rather than increased after administration of $\mathrm{mCPP}$; thus, if the influence of mCPP on dopamine cell firing is the same in awake rats as in anesthetized animals, the enhanced concentration of extracellular concentrations of dopamine in the nucleus accumbens and the striatum is not attributable to an increase in dopamine cell firing. Rather, it may be suggested that the effect of $\mathrm{mCPP}$ on dopamine cell firing is secondary to 
the elevated extracellular concentrations of dopamine observed in these experiments and in the report by Benloucif and Galloway (1991). The present observations that the $\mathrm{mCPP}$-induced reduction in nigral dopamine cell firing rate was effectively counteracted by pretreatment either with a dopamine synthesis inhibitor ( $\alpha$-methyl-tyrosine) or with a dopamine $\mathrm{D}_{2}$ receptor antagonist (haloperidol) lend some support for this assumption.

When comparing the data from the in vivo microdialysis experiments with those from the electrophysiological study, the fact that an inhibition of the firing rate of nigral dopamine neurons was obtained with doses of $\mathrm{mCPP}(0.25-0.5 \mathrm{mg} / \mathrm{kg})$ considerably lower than the dose $(2.5 \mathrm{mg} / \mathrm{kg})$ shown to cause an increase in dopamine levels should be taken into consideration. Also, it should be emphasized that the electrophysiology experiments were undertaken in anesthetised animals, whereas, awake rats were used for microdialysis. Indeed, the marked increase in dopamine release observed in a previous study after local administration of $\mathrm{mCPP}$ into the striatum of anesthetised rats (Benloucif and Galloway 1991) does suggest that the effect of $\mathrm{mCPP}$ on dopamine release may be more pronounced in anesthetised than in awake animals.

The possibility that the effect of $\mathrm{mCPP}$ on dopamine concentrations in the terminal region of the dopaminergic nerve cells is attributable to a direct or indirect interaction with serotonergic receptors should not be excluded. Indeed, several previous studies indicate that serotonin may exert a stimulatory influence on dopaminergic synapses in striatum and nucleus accumbens (Benloucif and Galloway 1991; Nissbrandt et al. 1992; Yashimoto and McBride 1992; Parsons and Justice 1993; Yadid et al. 1994; however, see also Ugedo et al. 1989; Dewey et al. 1995).

\section{ACKNOWLEDGMENTS}

This study was supported by the Swedish Medical Research Council (grants nos. 8668, 9299, 10869, and 7484), Knut och Alice Wallenberg's Foundation, Gun and Bertil Stohne's Foundation, Fredrick and Ingrid Thuring's Foundation, Åke Wiberg's Foundation, Magnus Bergwall's Foundation, Söderström-Königska Nursing Home Foundation, and Ragnhild and Einar Lundströms Foundation. Excellent technical assistance was provided by Ms Inger Oscarsson.

\section{REFERENCES}

Auerbach SB, Rutter JJ, Juliano J (1991): Substitued piperazine and indole compounds increase extracullular serotonin in rat diencephalon as determined by in vivo microdialysis. Neuropharmacology 30:307-311

Baumann MH, Mash DC, Staley JK (1995): The serotonin agonist m-chlorophenylpiperazine (mCPP) binds to serotonin transporter sites in human brain. Neuroreport 6:2150-2152

Baumann MH, Rutter JJ, Auerbach SB (1993): Intravenous administration of the serotonin agonist m-chlorophenylpiperazine (mCPP) increases extracellular serotonin in the diencephalon of awake rats. Neuropharmacology 32:1381-1386

Benkelfat C, Murphy DL, Hill JL, George DT, Nutt D, Linnoila M (1991): Ethanol-like properties of the serotonergic partial agonists $\mathrm{m}$-chlorophenylpiperazine in chronic alcoholic patients. Arch Gen Psychiatr 48:383

Benloucif S, Galloway MP (1991): Facilitation of dopamine release in vivo by serotonin agonists: Studies with microdialysis. Eur J Pharm 200:1-8

Butcher SP, Fairbrother IS, Kelly JS, Arbuthnott GW (1988): Amphetamine-induced dopamine release in the rat striatum: An in vivo microdialysis study. J Neurochem 50: 346-355

Buydens-Branchey L, Branchey M, Fergeson P, Hudson J, McKernin C (1993): Euphorogenic properties of the serotonergic partial agonist $\mathrm{m}$-chlorophenylpiperazine in cocaine addicts. Arch Gen Psychiatr 50:1001

Carboni E, Di Chiara G (1989): Serotonin release estimated by transcortical dialysis in freely moving rats. Neuroscience 32:637-645

Carver JG, Grahame-Smith DG, Johnson ES, Madgwick Z (1993): The effects of 5-HT and m-chlorophenylpiperazine (m-CPP) on the efflux [3H]-5-HT from human perfused platelets. Br J Clin Pharmacol 35:473-478

Dewey SL, Smith GS, Logan J, Alexoff D, Ding Y-S, King P, Pappas N, Brodie JD, Asby Jr CR (1995): Serotonergic modulation of striatal dopamine measured with positron emission tomography (PET) and in vivo microdialysis. J Neurosci 15:821-829

Eriksson E, Humble M (1990): Serotonin in psychiatric pathophysiology. A review of data from experimental and clinical research. In Gershon S, Pohl R (eds), The Biological Basis of Psychiatric Treatment, Progress in Basic Clinical Pharmacology, vol 3. Basel: Karger, pp 66-119

Freo U, Soncrant TT, Ricchieri GL, Wozniak KM, Larson DM, Rapoport SI (1990): Time courses of behavioral and regional cerebral metabolic responses to different doses of meta-chlorophenylpiperazine in awake rats. Brain Res 511:209-216

Fuller RW, Snoddy HD, Mason NR, Owen JE (1981): Disposition and pharmacological effects of m-chlorophenylpiperazine in rats. Neuropharmacology 20:155-162

Gardier AM, Kaakkola S, Erfurth A, Wurtman RJ (1992): Effects of methiothepin on changes in brain serotonin release induced by repeated administration of high doses of anorectiv serotoninergic drugs. Brain Res 588: $67-74$

George DT, Nutt DJ, Rawlings RR, Phillips MJM, Eckardt MJ, Potter WZ, Linnoila M (1995): Behavioral and endocrine responses to clomipramine in panic disorder patients with or without alcoholism. Biol Psychiatr 37: 112-119

Grace AA, Bunney BS (1983): Intracellular and extracellular electrophysiology of nigral dopaminergic neurons-1. 
Identification and characterization. Neuroscience 10: 301-315

Hekmatpanah CR, McKenna DJ, Peroutka SJ (1989): Reserpine does not prevent 3,4-methylenedioxymethamphetamine-induced neurotoxicity in the rat. Neurosci Lett 104:178-182

Hollander E, DeCaria C, Gully R, Nitescu A, Suckow RF, Gorman JM, Klein DF, Liebowitz MR (1991): Effects of chronic fluoxetine treatment on behavioral and neuroendocrine responses to meta-chlorophenylpiperazine in obsessive-compulsive disorder. Psychiatr Res 36:1-17

Huang X, Marona-Lewicka D, Nichols DE (1992): p-Methylthioamphetamine is a potent new non-neurotoxic serotonin-releasing agent. Eur J Pharmacol 229:31-38

Iqbal N, Asnis GM, Wetzler S, Kahn RS, Kay SR, van Praag HM (1991): The MCPP challenge test in schizophrenia: Hormonal and behavioral responses. Biol Psychiatr 30: 770-778

Ivernizzi R, Fracasso C, Caccia S, Garattini S, Samanin R (1991): Effects of intracerebroventricular administration of d-fenfluramine and d-norfenfluramine, as a single injection or 2-h infusion, on serotonin in brain: Relationship to concentrationa of drugs in brain. Neuropharmacology 30:119-123

Kahn RS, Siever LJ, Gabriel S, Amin F, Stern RG, DuMont K, Apter S, Davidson M (1992): Serotonin function in schizophrenia: Effects of meta-chlorophenylpiperazine in schizophrenic patients and healthy subjects. Psychiatr Res 43:1-12

Kahn RS, Wetzler S (1991): m-Chlorophenylpiperazine as a probe of serotonergic function. Biol Psychiatr 30:11391166

Kelland MD, Freeman AS, Chiodo LA (1990): Serotonergic afferent regulation of the basic physiology and pharmacological responsiveness of nigrostriatal dopamine neurons. J Pharm Exp Ther 253:803-811

Krystal JH, Seibyl JP, Price LH, Woods SW, Heninger GR, Aghajanian GK, Charney DS (1993): m-Chlorophenylpiperazine effects in neuroleptic-free schizophrenic patients. Evidence implicating serotonergic systems in the positive symptoms of schizophrenia. Arch Gen Psychiatr 50:624-635

Krystal JH, Webb E, Cooney N, Krazler HR, Charney DS (1994): Specificity of ethanol-like effects elicited by serotonergic and noradrenergic mechanisms. Arch Gen Psychiatr 51:898-911

Lagerkvist S (1991): Sample splitting provides a fast and selective method for determining brain dialysate dopamine and its metabolites. In Rollema H, Westerink B, Drijhout WJ (eds), Monitoring Molecules in Neuroscience. Meppel, The Netherlands, Krips Repro, pp 136138

Lucki I, Ward HR, Frazer A (1989): Effect of 1-(m-Chlorophenyl)Piperazine and 1-(m-Trifluoromethylphenyl)Piperazine on locomotor activity. J Pharm Exp Ther 249:155164

Mai J, Moryl E (1992): Effects of sertraline and citalopram given repeatedly on the responsiveness of 5-HT receptor subpopulations. J Neural Transm 88:143-156

Marshall BD Jr, Glynn SM, Midha KK, Hubbard JW, Bowen LL, Banzett L, Mintz J, Liberman RP (1989): Adverse effects of fenfluramine in treatment refractory schizophrenia. J Clin Psychopharmacol 9:110-115

Matos FF, Rollema H, Basbaum AI (1990): Characterization of monoamine release in the lateral hypothalamus of awake, freely moving rats using in vivo microdialysis. Brain Res 528:39-47

Moghaddam B, Bunney BS (1989): Ionic composition of microdialysis perfusing solution alters the pharmacological responsiveness and basal outflow of striatal dopamine. J Neurochem 53:652-654

Murphy DL, Lesch KP, Aulakh CS, Pigott TA (1991): III. Serotonin-selective arylpiperazines with neuroendocrine, behavioral, temeperature, and cardiovascular effects in humans. Pharmacol Rev 43:527-552

Nissbrandt H, Walters N, Hjorth S (1992): The influence of serotonergic drugs on dopaminergic neurotransmission. Naunyn-Schmiedeberg's Arch Pharmacol 346:12-19

Parsons LH, Justice JB Jr (1993): Perfusate serotonin increases extracellular dopamine in the nucleus accumbens as measured by in vivo microdialysis. Brain Res 26:195-199

Paxinos S, Watson C (1986): The rat brain in stereotaxic coordinates. Sydney, Academic Press

Pettibone DJ, Williams M (1984): Serotonin-releasing effects of substituted piperazines in vitro. Biochem Pharmacol 33:1531-1535

Prisco S, Pagannone S, Esposito E (1994): Serotonin-dopamine interaction in the rat ventral tegmental area: An electrophysiological study in vivo. J Exp Pharm Ther 271:83-90

Rutter JJ, Auerbach SB (1993): Acute uptake inhibition increases extracellular serotonin in the rat forebrain. J Pharmacol Exp Ther 265:1319-1324

Sabol KE, Richards JB, Seiden L (1992a): Fenfluramineindiced increase in extracellular hippocampal serotonin are progressively attenuated in vivo during a 4-day fenfluramine regimen in rats. Brain Res 571:64-72

Sabol KE, Richards JB, Seiden LS (1992b): Fluoxetine attenuates the DL-fenfluramine-induced increase in extracellular serotonin as measured by in vivo dialysis. Brain Res 585:421-424

Santiago M, Westerink BHC (1990): Characterization of the in vivo release of dopamine as recorded by different types of intracerebral microdialysis probes. NaunynSchimiedeberg's Arch Pharmacol 342:407-414

Soper HV, Elliott RO Jr, Rejzer AA, Marshall BD Jr (1990): Effects of fenfluramine on neuropsychological and communicative functioning in treatment-refractory schizophrenic patients. J Clin Psychopharmacol 10:168-175

Tao R, Hjorth S (1992): Differences in the in vitro and in vivo 5-hydroxytryptamine extraction performance among three common microdialysis membranes. J Neurochem 59:1778-1785

Targum SD, Marshall LE (1989): Fenfluramine provocation of anxiety in patients with panic disorder. Psychiatr Res 28:295-306

Trulson ME, Jacobs BL (1976): Behavioral evidence for the rapid release of CNS serotonin by PCA and fenfluramine. Eur J Pharmacol 36:149-154

Ugedo L, Grenhoff J, Svensson TH (1989): Ritanserin, a 5-HT2 receptor antagonist, activates midbrain dopamine neu- 
rons by blocking seroronergic inhibition. Psychopharmacology 98:45-50

Ulrichsen J, Partilla JS, Dax EM (1992): Long-term administration of $\mathrm{m}$-chlorophenylpiperazine (mCPP) to rats induces changes in serotonin receptor binding, dopamine levels, and locomotor activity without altering prolactin and corticosterone secretion. Psychopharmacology 107:229-235

Waters N, Lagerkvist S, Löfberg L, Piercey M, Carlsson A (1993): The dopamine $\mathrm{D}_{3}$ receptor and autoreceptor preferring antagonists (+)-AJ76 and (+)-UH232: A microdialysis study. Eur J Pharmacol 242:151-163

Wikander I, Roos T, Stakkestad A, Eriksson E (1995): Sodium lactate elicits a rapid increase in blood pressure in Wistar rats and spontaneously hypertensive rats:
Effect of pretreatment with the antipanic drugs clomipramine and alprazolam. Neuropsychopharmacology 12:245-250

Yadid G, Pacak K, Kopin IJ, Goldstein DS (1994): Endogenous serotonin stimulates striatal dopamine release in conscious rats. J Pharm Exp Ther 270:1158-1165

Yashimoto K, McBride WJ (1992): Regulation of nucleus accumbens dopamine release by the dorsal raphe nucleus in the rat. Neurochem Res 17:401-407

Zohar J, Insel TR, Zohar-Kadouch RC, Hill JL, Murphy DL (1988): Serotonergic responsivity in obsessive-compulsive disorder: Effects of chronic clomipramine treatment. Arch Gen Psychiatr 45:167-172 